\title{
Cytology of the Genus Cleome Linn.
}

\author{
Jolly K. Koshy and P.M. Mathew \\ Department of Botany, University of Kerala, \\ Kariyavattom, Trivandrum, India
}

Accepted September 9, 1983

The genus Cleome (Capparidaceae) comprises about 80 species which are chiefly tropical, most of them being distributed in the tropical Africa. The genus is represented in the Indian subcontinent by 13 species (Hooker 1872, Gamble 1956). Chromosome numbers of 22 species are previously known from different geographical regions (Fedorov 1969, Hanumantha Rao et al. 1979, Bhavanandan 1975, Pilz 1980, Sarkar et al. 1980, Balamani et al. 1981, Jolly Koshy and Mathew 1982). The present paper deals with the cytology of eight species from South India.

\section{Material and methods}

The species of Cleome reported here are common herbaceous weeds occurring in South India. They were collected from different localities in Kerala and Tamil Nadu such as Trivandrum, Quilon (C. aspera Koenig ex Dc., C. Burmanni W. et A., C. gynandra L., C. monophylla Linn., C. speciosa Raf., C. tenella Linn. and C. viscosa Linn.) Wynad and Ootacamund (C. spinosa L.). Chromosome studies were made from PMCs at meiosis. Flower buds were fixed in 3:1 Carnoy's fluid, and stained in lacto- propionic orcein (Dyer 1963). Pollen fertility was assessed on the basis of stainability of pollen grains in 1:1 mixture of acetocarmine and glycerine.

\section{Observation}

C. aspera is a spreading asperous herb. Two cytotypes of this species were noticed from this region, one with $n=12$ (Jolly Koshy and Mathew 1982) and the other with $\mathrm{n}=11$ (Fig. 1). Subsequent stages of meiosis were normal, and there was $91.8 \%$ fertile pollen grains. Hanumantha Rao et al. (1979) have earlier reported $\mathrm{n}=12$ in this species.

C. Burmanni is a glabrous herb with violet flowers. This species also shows two cytotypes in this region, one with $n=12$ (Jolly Koshy and Mathew 1982) and the other with $n=11$. Normal bivalent formation was noticed in about $55 \%$ of the PMCs of the present $n=11$ taxon (Fig. 2). Varying numbers of univalents were noticed in the rest of the cells, and there was irregular separation of chromosomes at anaphase, and this has resulted in considerable fall in pollen fertility in the taxon $(45 \%)$.

C. gynandra is a herb with white flowers. Seventeen bivalents were observed in bulk of the PMCs examined (Fig. 3). In about $20 \%$ of the cells $1-3$ secondarily 
associated bivalents were noticed. Figure 4 shows one cell with three secondary associations of bivalents. The material showed $75 \%$ fertile pollen grains. Previous workers reported varying chromosome numbers in the species such as $n=17$ (Balamani et al. 1981), $\mathrm{n}=16$ (Rao 1936) and $\mathrm{n}=15$ (Sugiura 1937).

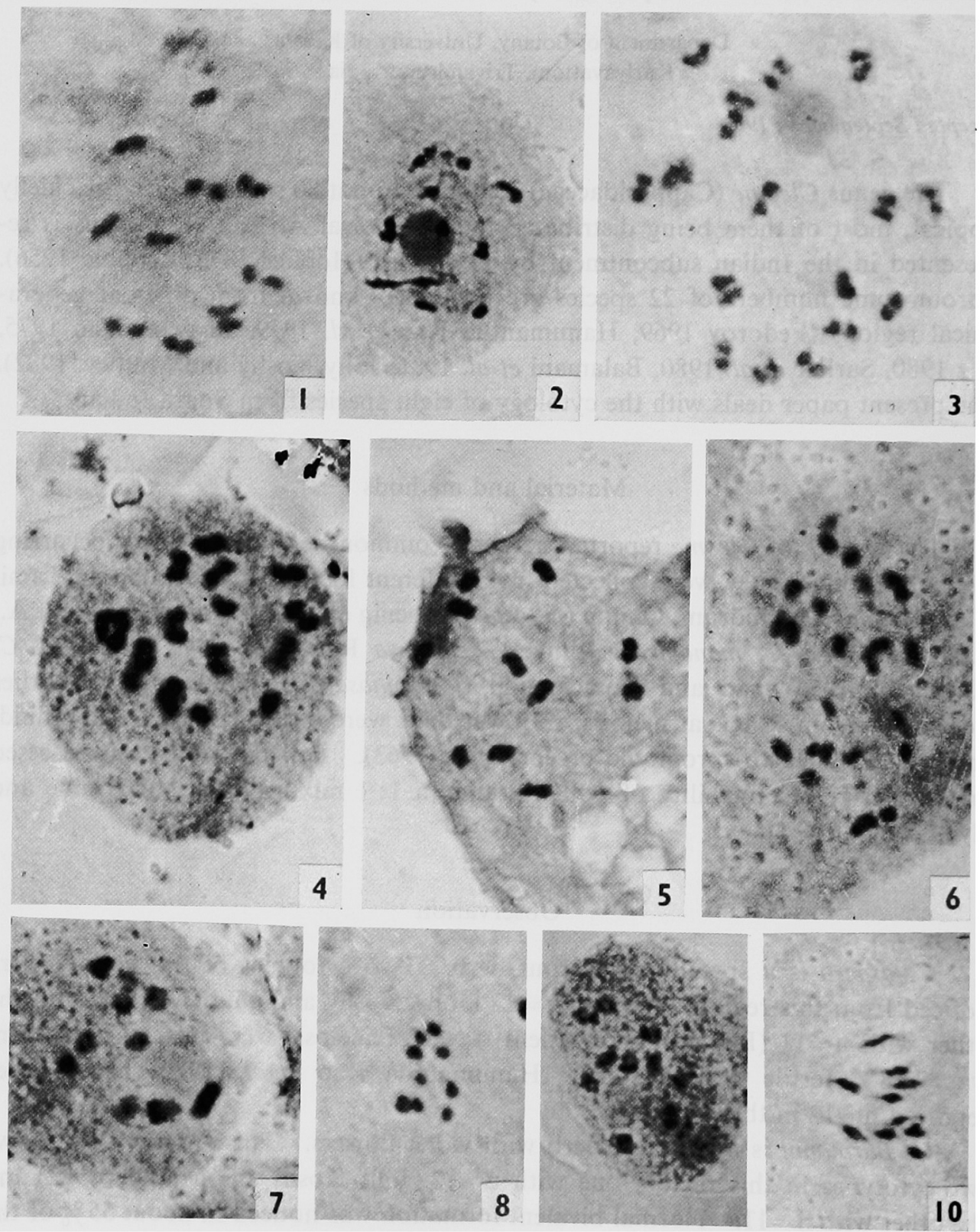

Figs. 1-10. Meiotic chromosomes of 8 species of Cleome. All photographs $\times 1500.1, C$. aspera, showing 11 bivalents at diakinesis. 2, C. Burmanni, showing 11 bivalents at diakinesis. 3, C. gynandra, showing 17 bivalents at diakinesis in PMCs. 4, C. gynandra. Another PMC showing three secondary association of bivalents. 5, C. monophylla, showing 11 bivalents. 6, C. speciosa, showing 14 bivalents and 8 univalents at diakinesis. 7, C. spinosa, showing 10 bivalents. 8 , another cytotype of $C$. spinosa with $\mathrm{n}=9$. 9, C. tenella, showing 11 bivalents at diakinesis.

10, C. viscosa, showing 10 bivalents at metaphase I. 
C. monophylla is an erect herb with pinkish flowers. Eleven bivalents were observed at diakinesis (Fig. 5). Meiosis was normal and there was appreciable pollen fertility $(85 \%)$.

C. speciosa is an erect herb with pink or white flowers. In the white-flowered variety studied here, bulk of the PMCs showed varying number of bivalents and univalents at diakinesis. Figure 6 shows a cell with 14 bivalents and 8 univalents. Bivalent formation was however, noticed in about $15 \%$ of the cells. Anaphase separation was irregular in the cells which possessed both bivalents and univalents, and as a result there was substantial reduction in pollen fertility $(23 \%)$. The pink variety reported earlier (Jolly Koshy and Mathew 1982) showed normal meiosis $(\mathrm{n}=18)$.

C. spinosa. Materials of this were collected from two different regions in South India, one from the high altitude region of the Western Ghats (Ootacamund), and the other from the plains of North Kerala (Wynad). Plants from the high altitude regions were considerably taller (7-9 ft.) and they showed 10 bivalents in PMCs at meiosis (Fig. 7); and those from the plains were only 3-5 ft. high, and they consistently showed only 9 bivalents (Fig. 8). The size of the bivalents in the $n=9$ taxon was significantly smaller. Both materials showed appreciable pollen fertility $(75-80 \%)$. A variety of haploid numbers were previously reported in the species such as $n=10$ (Ufer 1937), $n=12$ (Sugiura 1937a, b) and $n=19$ (Taylor 1925).

C. tenella is a spreading yellow-flowered herb. Eleven bivalents were observed at diakinesis (Fig. 9). Melosis was normal, and there was appreciable pollen fertility.

C. viscosa is an erect yellow-flowered herb. Ten bivalents were observed at diakinesis and metaphase I stages (Fig. 10). Meiosis was normal, and there was $90 \%$ pollen fertility. The same haploid count was reported in the species previously by Janaki Ammal (1933) and Balamani et al. (1981); but Raman and Kesavan (1963) have reported $n=24$.

\section{Discussion}

Available chromosome data on Cleome show that an array of haploid numbers $(\mathrm{n}=9,10,11,12,15,16,17,18,19,24,29,30,35$ and 70$)$ exists in the genus studied from different geographical regions. Some of the earlier workers (Raghavan and Venkatasubban 1940) on the family Capparidaceae, at a time when very little chromosome information was available, had contended that $x=7$ is the likely primary basic number of the entire family, and from this a number of secondary basic numbers have arisen and that the various genera of the family represent different balances of these numbers. However, it may be noted that in the genus Cleome no species based on $\mathrm{x}=7$ is so far known. More recently Hanumantha Rao et al. (1979) have held that the genus is polybasic with $x=9,10,11$ and 12 . From the distribution of different haploid numbers in the genus it appears that species of Cleome fall under a wider range of basic series, and they can be grouped under two classes such as $x=9,10,11,12$ and $x=15,16,17,18,19$. Of these $x=10$ shows overwhelming preponderance, being present in 11 out of the 22 species cytologically known. The predominance of $x=10$ condition together with oc- 
currence of species with high levels of polyploidy on this number $(\mathbf{n}=30,70)$ may be suggestive of $x=10$ being the earlier evolved chromosome constitution in the genus. On such a consideration, the other basic numbers in class I mentioned above must be aneuploid derivatives from this in both ascending and descending directions. Occurrence of intraspecific aneuploid cytotypes as in C. spinosa with $\mathrm{n}=9,10$ from South India (present report) and $\mathrm{n}=12$ from elsewhere (Sugiura $1937)$ and also in C. aspera $(\mathrm{n}=11,12)$ and $C$. Burmanni $(\mathrm{n}=11,12)$ from South India appears to support this possibility.

Bhavanandan (1975) has reported $\mathrm{n}=15$ in C. ciliata from South India, and he observed regular bivalent formation in the material. This $n=15$ species could be an allopolyploid, in the origin of which an $n=5$ species must have contributed. If this speculation is correct, then $x=5$ could be the ancestral chromosome constitution of the genus, from which the frequently occurring $x=10$ condition evolved by polyploidy. Occurrence of species of Cleome with $n=35$ (Ufer 1927) further supports this possibility.

In the other class of basic numbers in the genus $(x=15,16,17,18$ and 19) $x=17$ and 16 are more frequent. In a few species, cytotypes with two or more of the above numbers are known, such as $C$. gynandra $(\mathrm{n}=17,16,15)$ and $C$. serrulata $(\mathrm{n}=17,16)$. It is possible that these constitutions might be tertiary conditions derived by progressive aneuploid reduction from an $n=20$ polyploid based on $\mathrm{x}=10$. The $\mathrm{n}=29$ situation reported in C. lechleri (Huynh 1965) could be an aneuploid derived from a still higher polyploid $(n=30)$, also on $x=10$. The overall chromosome data in the genus thus appears to be much in favour of considering $\mathbf{x}=10$ as the earlier evolved condition in the genus which in turn possibly originated from an ancestral $x=5$ condition, the other constitutions being evolved by descending and/ascending aneuploidy at the diploid as well as higher polyploid levels on $x=10$. The data also indicate that polyploidy and widespread aneuploidy at different ploidy levels may have been actively operative in speciation and evolution of the genus.

\section{Summary}

Cytology of eight species of Cleome indigenous to South India has been reported, namely C. aspera $(\mathrm{n}=11,12), C$. Burmanni $(\mathrm{n}=11,12), C$. gynandra $(\mathrm{n}=17), C$. monophylla $(\mathrm{n}=11), C$. speciosa $(\mathrm{n}=18)$, C. spinosa $(\mathrm{n}=10,9)$, C. tenella $(\mathrm{n}=11)$ and $C$. viscosa $(\mathrm{n}=10)$.

Chromosome records show that the members of the genus fall under a wide range of basic series $(x=9$ to 19$)$ which can be grouped under two classes such as $x=9,10,11,12$ and $x=15,16,17,18,19$. Species based $x=10$ shows overwhelming preponderance and it is considered that $x=10$ could be the earlier evolved condition in the genus from which the other basic series in the former class evolved by ascending and descending aneuploidy. It is also suggested that $x=10$ was possibly originated from an ancestral $x=5$ condition. The species in the latter class of basic numbers are considered to be tertiary conditions evolved by polyploidy on $\mathrm{x}=10$, followed by progressive aneuploid reduction. 
The chromosome data indicate that polyploidy and widespread aneuploidy may have played significant role in speciation and evolution of the genus.

\section{Acknowledgement}

We are thankfull to Prof. C. A. Ninan, Head of the Department of Botany for helpful suggestions and encouragement. One of us (JK) is grateful to the UGC for the award of a Research Fellowship.

\section{References}

Balamani, G. V. A. and Rao., Rolla S. 1981. IOPB chromosome number reports LXXIII. Taxon 30: 856.

Bhavanandan, K. V. 1975. Chromosome number of Cleome ciliata. Sci. and Cult. 41: 403-404.

Dyer, A. F. 1963. The use of lacto- propionic orcein in rapid squash methods for chromosome preparations. Stain Technol. 38: 85-89.

Fedorov, A. 1969. Chromosome Numbers of Flowering Plants. (ed.) V. L. Komorov Botanical Institute.

Gamble, J. S. 1956. Flora of the Presidency of Madras. Vol. I. Botanical Survey of India.

Hanumantha Rao, B., Lakshmy, N. and Prakasa Rao, P. S. 1979. Chromosome number and meiosis in Cleome aspera Linn. Curr. Sci. 48: 730-731.

Hooker, J. D. 1872. The Flora of British India. Vol. I. L. Reeve and Co. London.

Huynh, K. L. 1965. Contribution a l'étude caryologique et embryologique des Phanérogames du Pérou.- Schweiz. Naturforsch. Ges. Mém. Soc. Helvétique. Sci. Nat. 85: 1-178.

Janaki Ammal, E. K. 1933. The chromosome number of Cleome viscosa Linn. Curr. Sci. 1: 328.

Jolly Koshy, K. and Mathew, P. M. 1982. IPOB chromosome number reports LXXVII. Taxon 31: 773.

Pilz George, E. 1980. IOPB chromosome number reports LXVII. Taxon 29: 352.

Raghavan, T. S. and Venkatasubban, K. R. 1941. Studies in the Capparidaceae. The cytology of Capparis zeylanic Linn. and related genera. Cytologia 11: 319-331.

Raman, V.S. and Kesavan, P. C. 1963. Chromosome numbers of a few horticultural plants. Sci. and Cult. 29: 609-610.

Rao, V.S. 1936. Studies on Capparidaceae. The embryology of Gynandropsis pentaphylla. J. Indian Bot. Soc. 15: 335.

Sarkar, A. K., Chakraverty, M., Das, S. K., Pal, C. R. and Hazara, D. 1980. IOPB chromosome number reports LXVII. Taxon 29: 359.

Sugiura, T. 1937a. Studies on chromosome numbers in higher plants, with special reference to cytokinesis. II. Cytologia Fujii Jub. Vol. pt. 2: 845-849.

- 1937b. A list of chromosome numbers in angiospermous plants. Bot. Mag. (Tokyo) 51 : $425-426$.

Taylor, W. R. 1925. Chromosome constrictions as distinguishing characteristics in plants. Amer. J. Bot. 12: 238-244.

Ufer, M. 1927. Vergleichende Untersuchungen über Cleome spinosa, Cleome gigantea und ihren Gigas-Formen. Diss. Hamburg. 1-57.

- 1937. Erblichkeitsuntersuchungen an Cleome spinosa und ihren Gigas-Formen. Zeitschr. Indukt. Abstamm. u. Vererbungslehre 73: 390-393. 